Jurnal Keperawatan Silampari

Volume 5, Nomor 1, Desember 2021

e-ISSN: 2581-1975

p-ISSN: 2597-7482

DOI: https://doi.org/10.31539/jks.v5i1.2918

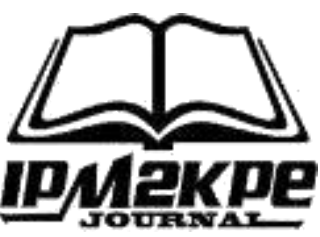

\title{
POLA KONSUMSI PASIEN COVID-19 YANG MELAKUKAN ISOLASI MANDIRI SELAMA PPKM LEVEL 4
}

\author{
Apris A. Adu ${ }^{1}$, Daniela Boeky ${ }^{2}$ \\ Universitas Nusa Cendana ${ }^{1,2}$ \\ apris.adu@staf.undana.ac.id ${ }^{1}$
}

\begin{abstract}
ABSTRAK
Penelitian ini bertujuan untuk mengetahui pola konsumsi pasien COVID-19 selama melakukan isolasi mandiri di masa PPKM Level 4 di kota Kupang. Metode penelitian yang dilakukan adalah penelitian kuantitatif dengan desain penelitian cross sectional study. Hasil penelitian menunjukkan bahwa pola konsumsi dari segi jenis makanan yang dikonsumsi ada pada kategori sedang dengan jumlah 46 responden $(57,5 \%)$, dari segi jumlah makanan ada pada kategori baik dengan jumlah 63 responden $(78.75 \%)$ dan dari segi frekuensi makan ada pada kategori baik sebanyak 72 respoden (90\%). Banyaknya informasi tentang makanan bergizi seimbang membuat pasien isoman sudah lebih bijak dalam memilih dan mengkonsumsi makanan untuk meningkatkan imunitas dan mempercepat proses pemulihan. Simpulan, cara mendapatkan bahan makanan pasien COVID-19 selama masa PPKM level 4 di kota Kupang yakni lebih banyak di peroleh dari bantuan keluarga, pola konsumsi pada kategori dan jumlah makanan yang di konsumsi baik.
\end{abstract}

Kata Kunci : COVID-19, Isolasi Mandiri, PPKM, Pola Konsumsi

\section{ABSTRACT}

This study aims to determine the consumption patterns of COVID-19 patients during self-isolation during PPKM Level 4 in the city of Kupang. The research method used is quantitative research with a cross-sectional study design. The results showed that the consumption pattern in terms of the type of food consumed was in the moderate category with a total of 46 respondents (57.5\%), in terms of the amount of food in the excellent class with a total of 63 respondents (78.75\%) and in terms of the frequency of eating there was at the good category as many as 72 respondents (90\%). The amount of information about balanced nutritious foods makes isoman patients wiser in choosing and consuming foods to increase immunity and speed up the recovery process. In conclusion, getting food for COVID-19 patients during PPKM level 4 in Kupang city, mainly obtained from family assistance, consumption patterns in categories, and the amount of food consumed, is good.

Keywords: COVID-19, Independent Isolation, PPKM, Consumption Pattern 


\section{PENDAHULUAN}

Saat ini dunia sedang melakukan perjuangan yang sama untuk melawan musuh tak terlihat. Kemudian perhatian dunia harus fokus pada virus baru COVID-19, yang menuntut perhatian dunia untuk dapat melalui dampak dari virus ini yang perlu dipikirkan bersama jalan keluarnya. Wabah COVID-19 terus menyebar tanpa memberikan tanda kapan akan selesai, mengakibatkan banyak aktivitas normal manusia yang terpaksa beralih menjadi aktivitas yang dilakukan dari rumah menggunakan sistem dalam jaringan (daring), seperti bekerja, belajar, sekolah dan berbagai aktivitas lain (Choertunnisa, 2020). Penyebaran COVID-19 menjadi berita utama hampir diseluruh dunia yang semakin berkembang sejak Desember 2019. World Health Organization (WHO) kemudian menetapkan COVID-19 menjadi status pandemi karena penyebaran telah terjadi secara sporadis hampir ke seluruh dunia dalam tiga bulan sejak merebak. (WHO, 2020). Hingga 5 September 2021, tercatat lebih dari 219 juta kasus konfirmasi positif COVID-19 di seluruh dunia, dengan jumlah orang meninggal diseluruh dunia berjumlah 4.55 juta kasus. (WHO, 2021).

Pemerintah mengumumkan secara resmi kasus COVID-19 pertama di Indonesia pada tanggal 2 maret 2020. Dua warga Indonesia yang positif mengatakan bahwa melakukan kontak langsung dengan warga Negara Jepang yang sedang berkunjung ke Indonesia. Tanggal 11 maret 2020, untuk pertama kalinya ada kasus meninggal diakibatkan karena virus corona tersebut. Korban yang meninggal adalah pria berusia 59 tahun warga asal solo. Diketahui dia tertular setelah menghadiri seminar di Bogor pada bulan Februari. Penyebaran virus corona di Indonesia ini tersebar di 34 provinsi di Indonesia (Nusofwa et al., 2020). Sementara itu data di Indonesia hingga 28 Januari 2021, wabah telah menginfeksi sebanyak 1.037 .993 orang dengan 29.331 orang diantaranya meninggal dunia dan 842.122 orang lainnya dinyatakan sembuh (SatgasCovid19, 2021).

Penyebaran COVID-19 di Indonesia yang sangat cepat menyebabkan hampir semua rumah sakit penuh dengan pasien COVID-19 (Nuraini, 2020). Dalam menghadapi pandemi COVID-19 ini, pemerintah Indonesia menelurkan berbagai kebijakan tentang kegiatan preventif dan pengendalian COVID-19, yang terus diubah sesuai dengan perkembangan penanganan COVID-19. Salah satu kebijakan yang ditempuh adalah menerapkan isolasi mandiri untuk mencegah penularan wabah. Isolasi harus dimaknai sebagai upaya pengurangan resiko penularan penyakit. Individu yang sakit dipisahkan dengan yang sehat, yang dinyatakan terinveksi atau diduga mempunyai gejala seperti COVID-19 dipisahkan dengan yang tidak bergejala (Kemenkes-RI, 2020). Implementasi kebijakan ini sangat penting untuk pencegahan penyakit, sehingga sudah semestinya diikuti pengawasan yang lebih ketat.

Dalam kondisi pandemi, isolasi mandiri dapat diterapkan ketika mengalami sakit tenggorokan, batuk, gejala saluran pernafasan, dan gejala lainnya. Isolasi dilakukan dengan tidak bepergian, menetap di dalam rumah selama kurang lebih dua pekan. Menurut Kementerian Kesehatan, isolasi mandiri yang dilakukan di dalam rumah, agar dipisahkan dengan anggota keluarga yang lain (Kemenkes-RI, 2020).

Pola isolasi nampak sederhana, namun sangat sulit dilakukan semua orang. Padahal menurut Butar-Butar, isolasi adalah cara menghindari penularan penyakit yang efektif agar penyakit tidak meluar (Butar-Butar, 2020).

Dengan demikian, isolasi mandiri menjadi sangat penting sebagai tindakan pencegahan. Kondisi ini membuat pemerintah mengambil kebijakan bagi pasien yang tanpa gejala dan ringan dapat melakukana isolasi isolasi mandiri (isoman) di rumah. 
Kebijakan yang dilakukan dan dianjurkan kepada pasien yang melakukan isolasi mandiri bervariasi waktunya pasien tanpa gejala adalah 10 hari, untuk pasien gejala ringan selama10 hari ditambah 3 hari yang sudah bebas dari berbagai gejala sedangkan yang kontak erat lebih lama waktunya yakni 14 hari sejak kontak (Kemenkes-RI, 2020).

Sejak pandemi COVID-19, berbagai kebijakan yang telah diusahakan oleh Pemerintah untuk dapat mengontrol peningkatan kasus COVID-19 di Indonesia. Di mulai dari PSBB, PSBB Transisi, PPKM Darurat, hingga yang terakhir PPKM 4 level. Penetapan level setiap wilayah didasarkan pada indikator penyesuaian yang ditetapkan oleh Menteri Kesehatan dengan mengacu pada panduan WHO. Penetapan level 4 didasarkan pada temuan kasus COVID-19 sebanyak 150 kasus per populasi 100.000 orang setiap minggunya, jumlah pasien inap sebanyak 30 pasien per populasi 100.000 orang setiap minggunaya, dan mortilitas COVID-19 $>5$ pasien setiap populasi 100.000 orang (WHO, 2021).

Pembatasan aktivitas dalam suatu wilayah tentu akan berdampak pada ketahanan pangan secara mendunia (Devereux et al., 2020). Akibat dari langkah membatasi aktivitas fisik diluar rumah ini terjadi perubahan dalam proses penyaluran bahan makanan, sehingga menimbulkan perubahan pada konsumsi masyarakat, bahkan hasil bumi masyarakat yang menjadi sampah karena menurunnya daya beli masyarakat selama pandemi atau rusak di jalan karena terjadi pembatasan mobilitas.

Kota Kupang merupakan salah satu wilayah yang masuk dalam kategori PPKM level 4. Data kasus COVID-19 per tanggal 5 September 2021 adalah 14.692 kasus dengan jumlah orang meninggal sebanyak 369 orang dan pasien sembuh 13.832 orang. Pandemi COVID-19 ini telah menyebabkan gangguan sosio-ekonomi dan kekhawatiran luas tentang kurangnya persediaan bahan makanan di masyarakat. Pembatasan jam operasional pasar juga pembatasan jumlah orang yang melakukan aktivitas jual-beli di pasar membuat banyak pihak merasa khawatir akan kebutuhan bahan makanan (Diskominfo, 2021).

Pola konsumsi adalah informasi tentang jenis, jumlah dan frekuensi makanan yang dapat digunakan sebagai dasar untuk menentukan jumlah asupan gizi harian pada suatu kelompok (Larasati, 2020). Mereka yang isolasi mandiri terkadang menghadapi kendala dalam memenuhi kebutuhan makanan karena sedang dikarantina sehingga berdampak pada ketersediaan bahan makanan untuk memenuhi kebutuhan selama menjalani isoman di rumah. Tidak sedikit dari mereka yang kemudian menjadi depresi karena keadaan ini. Padahal asupan makanan yang cukup selama isoman dapat membantu meningkatkan imunitas tubuh sehingga bisa segera pulih dari COVID-19 (Saragih, 2020).

Hal penelitian Achmad et al., (2020) menjelaskan bahwa pola pikir masyarakat perkotaan saat ini yang banyak mengalami perubahan, dimana kegiatan membeli barang lebih kepada fungsi sosial untuk menaikkan gengsi. Hal ini tidak terlepas dari fungsi media sebagai penyampai informasi sekaligus sebagai cara mempengaruhi pola pikir masyarakat.

Beberapa upaya yang dilakukan pasien yang terpapar COVID-19 yang melakukan isolasi mandiri untuk memenuhi kebutuhan akan makanan adalah dengan memanfaatkan aplikasi pesan antar makanan lewat grab food, alasannya adalah selain mudah dan gampang juga harganya tidak mahal, selain itu waktu untuk istirahat mereka cukup dan tidak mengeluarkan tenaga untuk memasak. Ada juga yang memanfaatkan jasa belanja sembako secara online untuk mencukupi bahan makanan 
agar bisa diolah sendiri. Beberapa upaya ini diharapkan dapat memenuhi pola konsumsi pasien isolasi mandiri dari segi jumlah, jenis, dan frekuensi makan demi meningkatkan imunitas tubuh pasien tersebut (Indraswari \& Kusuma, 2018). Penelitian Lembaga Demografi Fakultas Ekonomi dan Bisnis Universitas Indonesia (LD FEB UI) menunjukkan tingkat ketergantungan masyarakat terhadap layanan berbasis aplikasi yang bersifat daring semakin tinggi selama pandemi ini, seperti aplikasi GO-JEK. Disampaikan oleh LD FEB UI, layanan yang paling sering digunakan secara berurutan adalah Go-Food (65\%), Go-Pay (68\%), Paylater (57\%) dan Go-Send (36\%).

Hidayat (2020) dalam penelitiannya di Kota Medan menyatakan bahwa diterapkannya work from home, dan membatasi jumlah pelanggan rumah makan selama pandemi COVID-19 berdampak signifikan secara parsial dan simultan terhadap peningkatan pembelian makanan secara daring melalui aplikasi GO-FOOD. Sejalan dengan itu, hasil riset dari LD FEB UI juga menyatakan bahwa sebanyak $86 \%$ konsumen mengaku aplikasi daring tersebut sangat membantu untuk menyesuaikan dengan pola baru dan tetap dapat beraktivitas normal selama pandemi COVID-19. Peningkatan jumlah transaksi pada layanan pesan antar makanan dengan persentase yang sama juga terjadi pada perusahaan layanan jasa serupa, Grab (Yuniar, 2020).

Penelitian tentang pola konsumsi pasien COVID-19 yang melakukan isolasi mandiri selama PPKM level 4 ini masih jarang dilakukan, khususnya di tempat penelitian belum pernah dilakukan penelitian yang sama.

\section{METODE PENELITIAN}

Metode yang digunakan dalam penelitian ini adalah observasi analitik dengan desain penelitian cross sectional study. Penelitian ini akan distribusi menurut variable epidemiologi (waktu, tempat dan orang) kematian akibat terkena COVID-19 di kota Kupang, selama tahun 2020 sampai dengan bulan Mei 2021. Alat ukur yang dipakai saat penelitian berupa angket yang sebelumnya digunakan sudah dilakukan uji validasi.

Pengambilan data menggunakan aplikasi google form dengan alas an karena adanya pandemi COVID-19. Penelitian dilakukan sejak bulan Juni-Juli 2021 degan sampel yang digunakan 80 sampel dari populasi 389. Penentuan sampel menggunakan simpel random sampling. Teknik analisis data menggunakan persentase yang didasarkan pada hasil kriteria. Yang di sajikan dalam bentuk grafik, table dan narasi.

\section{HASIL PENELITIAN}

Tabel. 1

Cara Mendapatkan Bahan Makanan

\begin{tabular}{ccc}
\hline Cara Mendapatkan Bahan Makanan & $\mathrm{n}$ & $\%$ \\
\hline Minta tolong keluarga & 53 & 66.25 \\
Jasa belanja Sembako online & 27 & 33.75 \\
\hline Total & 80 & 100
\end{tabular}

Berdasarkan tabel 1 diperoleh sebanyak 53 responden (66.25\%) memilih untuk meminta tolong kepada keluarga atau kerabat untuk berbelanja ke pasar, kemudian mengantarkan ke rumah untuk kemudian diolah menjadi makanan. 
Tabel. 2

Jenis Makanan yang Dikonsumsi

\begin{tabular}{ccc}
\hline Jenis makanan & N & $\%$ \\
\hline Baik $(>5$ jenis $)$ & 25 & 31.25 \\
Sedang $(4-5$ jenis $)$ & 46 & 57.5 \\
Kurang $(\leq 3$ jenis $)$ & 9 & 11.25 \\
\hline Total & 80 & 100 \\
\hline
\end{tabular}

Berdasarkan table 2 mayoritas responden memiliki jenis makanan dengan kategori sedang yaitu sebanyak 46 responden (57.5\%). Jenis makanan yang dimaksud disini adalah kaya akan gizi seimbang, yakni mengandung protein, karbohidrat, lemak, vitamin dan mineral. Banyaknya informasi tentang jenis makanan yang dapat meningkatkan imunitas dan mempercepat proses pemulihan membuat responden sudah bisa memilih dan mengkonsumsi jenis makanan dengan zat gizi yang lebih kompleks dan seimbang.

Tabel. 3

Jumlah Makanan yang Dikonsumsi

\begin{tabular}{ccc}
\hline Jumlah makanan & $\mathrm{n}$ & $\%$ \\
\hline Baik $(\geq \mathrm{AKG})$ & 63 & 78.75 \\
Kurang $(<\mathrm{AKG})$ & 17 & 21.25 \\
\hline Total & 80 & 100
\end{tabular}

Berdasarkan tabel 3 menjelaskan sebanyak 63 responden $(78.75 \%)$ memiliki jumlah makanan dengan kategori baik. Jumlah makanan disini disesuaikan dengan AKG 2019, dimana jumlah kebutuhan kalori per hari adalah antara 1800-2550 kkal dan kebutuhan protein setiap hari adalah 60-65 gram. Pada masa pemulihan COVID19, pasien membutuhkan sumber kalori dan protein yang banyak agar dapat lebih memberikan efek kesembuhan dari infeksi. Kurangnya asupan energy dan protein dapat memperlambat proses penyembuhan dari infeksi.

Tabel. 4

Frekuensi Makan

\begin{tabular}{ccc}
\hline Frekuensi makan & $\mathrm{n}$ & $\%$ \\
\hline Baik $(\geq 3$ kali sehari $)$ & 72 & 90 \\
\hline Kurang $(<3$ kali sehari $)$ & 8 & 10 \\
\hline Total & 80 & 100 \\
\hline
\end{tabular}

Berdasarkan tabel 4 di atas, sebanyak 72 responden (90\%) memiliki frekuensi makan yang baik.

\section{PEMBAHASAN}

Saat ini pandemi COVID yang melanda dunia sangat berdampak pada berbagai sisis kehidupan terlebih pada ekonomi masyarakat, hampir semua orang mengeluh dengan kondisi ini, seperti adanya pengurangan pegawai atau pengurangan jam kerja yang akhirnya penghasilanpun berkurang. Akibat dari penghasilan yang turun berdampak pada daya beli keluarga yang ikut berkurang sehingga berbagai kebutuhan tidak terpenuhi dengan baik. 
Perubahan pola konsumsi masyarakat terhadap wabah yang dialami saat ini sangatlah tampak pada berbagai aktifitas yang terjadi di tempat-tempat penjualan seperti toko kelontong dan pasar. Pasar menjadi tempat untuk menyediakan berbagai aneka ragam kebutuhan pokok masyarakat secara langsung mengalami dampak yang sangat berat. Para penjual mengalami kerugian yang sangat besar akibat tidak lakunya barang dagangan, sepinya pembeli dikarenakan adanya ketakutan yang sangat luar biasa dari masyarakat terhadap terinveksi virus COVID-19 juga karena adannya kebijakan pemerintah terhadap pembatasan aktivitas masyarakat tersebut. Menurut Cartenì et al., (2020) kondisi ini menyebabkan masyarakat belum dapat menerima dengan adanya kebijakan pembatasan aktifitas. Adanya peningkatan kasus COVID-19 secara cepat menandakan tingkat ketaatan masyarakat yang rendahnya.

Kota Kupang sebagai pusat dari ibu kota provinsi dan kota, juga mengalami hal yang sama di mana hampir semua pasar sepi, para penjual lebih memilih menjual sisa barang yang tidak laku kemarin atau menurunkan jumlah dagangan mereka, hal ini sangat berdampak terhadap kebutuhan dan daya beli dari masyarakat khususnya pasien COVID-19 yang melakukan isolasi mandiri. Kesembuhan dari pasien yang melakukan isolasi mandir sangat bergantung pada kebutuhan mereka akan sumber gizi yang berasal dari berbagai makanan yang tersedia baik kuantitas maupun kualitasnya. Sumber makanan yang baik yang sering mereka dapatkan sendiri dari pasar harus di titip ke keluarga, keluarga sangat diharapkan membantu dalam menyediakan berbagai kebutuhan dari pasien yang mengalami sakit atau melalui pembelian secara daring, ini menyebabkan bahan makanan atau makanan yang mereka dapat sangat berbeda dengan keinginan dan selera makan mereka, akibatnya tingkat kesembuhan pasien isolasi mandiri di Kupang menurun dan lama, bahkan ada yang parah dan dibawa ke rumah sakit. Penelitian ini sejalan dengan (Larasati, 2020). Pola makan terjadi karena adanya kebiasaan makan setiap orang. Banyak faktor yang ikut dalam menentukan perubahan cara makan seperti pengaruh agama, ekonomi, sosial budaya, pendidikan, dan lingkungan keluarga dana sosial. Pola konsumsi masyarakat yang berbeda dipengaruhi oleh banyak faktor seperti pendapatan yang mempengaruhi daya beli, pengaruh lingkungan, dan karena kebutuhan.

Selama pandemi, jumlah asupan zat gizi menjadi meningkat yang diperlukan untuk dapat meningkatkan imunitas tubuh, khususnya zat gizi vitamin dan mineral. Imunitasi tubuh yang baik akan sangat membantu dalam membentengi diri dari terkena COVID-19 (DBG, 2020). Jumlah makanan yang dikonsumsi pasien selama melakukan isolasi mandiri secara umum baik namun memang adajuga yangmengalami konsumsi buruk. Baiknya konsumsi makan dari pasien ini karena adanya dukungan dari orang dekatnya yang sangat membantu dalam menyediakan berbagai kebutuhan makan dari pasien, dengan jumlah makanan yang tercukupi ini juga dipengaruhi oleh ekonomi dan daya beli dari pasien yang cukup baik, mereka meminta bantuan dari orang dekat untuk menyediakan segala makanan yang dibutuhkan sesuai kebiasaan mereka setiap hari. Kebanyakan makanan yang mereka makan pemenuhan karbohidrat dan protein lebih banyak dibandingkan dengan sayuran dan buah. Berdasarkan Permenkes RI tentang penyelenggaraan pelayanan kesehatan, salah satu metode penyampaian informasi dan edukasi masyarakat, khususnya mengenai gizi, dengan menggunakan metode telegizi untuk masyarakat umum maupun kepada pasien COVID-19. 
Frekuensi makanan dari pasien COVID-19 yang melakukan isolasi mandiri di kota Kupang menunjukan stabil minimal 3 kali sehari bahkan ada yang mengalami peningkatan. Frekuensi makan yang baik seperti ini menunjukan bahwa pasien COVID-19 di kota Kupang yang melakukan isolasi mandiri tidak bermasalah dan stress yang berlebihan, mereka merasa bahwa dalam melakukana isolasi mandiri tidak perlu takut berlebihan tapi harus konsumsi makan yang banyak agara cepat pulih. Penyaluran bahan makanan untuk asien COVID-19 menjadi hal yang penting untuk menjamin tersedianya makanan dengan kandungan gizi seimbang dan aman. Kebutuhan akan gizi yang seimbang oleh pasien adalah agar dapat menjaga dan mempertahankan imunitas dan daya tahan tubuh mereka. Imunitas tubuh yang baik pada pasien memberikan efek positif untuk membunuh kuman penyakit serta menghindari efek kecacatan dan membantu dalam proses kesembuhan pasien, gizi yang baik dan seimbang juga dapat memperbaiki jaringan, dan memulihkan kondisi homeostasis dalam tubuh sehingga tubuh tetap sehat (Salsabila, 2020).

\section{SIMPULAN}

Cara mendapatkan bahan makanan pasien COVID-19 selama masa PPKM level 4 di kota Kupang yakni lebih banyak di peroleh dari bantuan keluarga, pola konsumsi pada kategori dan jumlah makanan yang di konsumsi baik.

\section{SARAN}

Perlu adanya sosialisasi yang lebih luas menyangkut PPKM level 4, agar dapat diterima dan di lakukan oleh semua masyarakat Kota Kupang, serta perhatian yang lebih juga pada pasien yang melakukan isolasi di rumah agar bukan saja dari segi pengobatan tapi juga dari segi mendapatkan makanan serta bahan makanan yanga berkualitas.

\section{DAFTAR PUSTAKA}

Achmad, G. N., Adhimursandi, D., \& Rahmawati, R. (2020). The Influence of Whatsapp Advertisment on Purchase Decision to Increase Sales of Local Culinary Product in COVID-19 Pandemic. Journal of Critical Review, 4(4), 1-9. http://jurnal.stic.ass.ac.id/index.php/IJEBAR/article/view/1548/867

Butar-Butar, A. R. (2020). Kepustakaan Medis-pandemik di Dunia Islam. OIF UMSU, 29.Available https://ejournal.umm.ac.id/index.php/jie/article/view/6967

Cartenì, A., Di-Fransesco, L., \& Martino, M. (2020). How Mobility Habits Influenced the Spread of the COVID-19 Pandemic: Results from the Italian Case Study. Science of the Total Environment, 741.https;//doi.org/10/1016/j/scicoteny.2020.140489

Choertunnisa, V. (2020). Di Tengah Pandemi COVID-19, Kreativitas Pendidikan Tetap Dukung Pembelajaran. https://www.tanotofoundation.org/id/news/ino vasi-pendidikan-di-era-pandemi/

DBG, D. B. (2020). Telenutrition COVID-19 Seameo-Recfon. Jakarta: Webinar Asuhan Gizi dalam Masa Pandemi COVID-19 https://www.youtube.com/channel/UCyxXKeiIgEF_ikdyern_MQ [diakses pada tanggal 10 September 2020].

Devereux, S., Béné, C., \& Hoddinott, B. D. (2020). Conceptualising COVID-19 Impacts on Household Food Security. Security Food Journal, 12(4), 769-772. DOI: $10.1007 / \mathrm{s} 12571-020-01085-0$ 
Diskominfo. (2021).Pembatasan Operasional. Kupang: (@diskominfokotakupang)

Hidayat, T. (2020). Analisis Persepsi Konsumen terhadap Pembelian Makanan Secara Online Saat Pandemi COVID-19 (Kasus Fitur Go-Food). Sumatera: http://repository.usu.ac.idhandle/123456789/27798

Indraswari, A., \& Kusuma, H. (2018). Analisa Pemanfaatan Aplikasi Go-Food Bagi Pendapatan Pemilik Usaha Rumah Makan di Kelurahan Sawojajar Kota Malang. Jurnal Ilmu Ekonomi, 63-73. http://ejournal.umm.ac.id/index.php/jie/article/view/6967

Kemenkes-RI. (2020). Pedoman Penanganan Corona Virus Desease (COVID-19). Jakarta: Direktoral jenderal Pencegahan dan Pengendalian Penyakit

Kemenkes-RI. (2020). Pedoman Pencegahan dan Pnengendalian COVID-19, Germas. Jakarta: KEMENKES RI

Larasati, R. A. (2020). Pola Konsumsi Mahasiswa Pulang Kampung dan Masyarakat pada Pandemi COVID-19 di Kota Bandung. Jembura Economic Education Journal, 2(2), 90-99. DOI: 10.37479/jeej.v2i2.6840

Nuraini, R. (2020). Kasus COVID-19 Pertama, Masyarakat Jangan Panik. Jakarta: Narasi Indonesia. Available from URL: https://indonesia.go.id/narasi/indonesiadalam-angka/ekonimi/kasus-COVID-19-pertama-masyarakat-jangan-panik

Nursofwa, R. H., Syukur, M, H., Kurniadi, B., \& Haris, H. (2020). Penanganan Pelayanan Kesehatan di Masa Pandemi Covid-19 dalam Perspektif Hukum Kesehatan. Inicio Legis, 1(1), https://journal.trunojoyo.ac.id/iniciolegis/article/view/8822

Salsabila, T. (2020). Gambaran Pelayanan Gizi untuk Pasien Covid-19 di Rumah Sakit Darurat Covid-19 di Wisma Atlet Kemayoran. Poltekkes Kemenkes Jakarta

https://perpus.poltekkesjkt2.ac.id/respoy/index.php?p=show_detail\&id=3674\&k eywords=

Saragih, B. (2020). Hubungan Berbagai Faktor dengan Kebiasaan Makan pada Masa Pandemi COVID-19. ResearchGate, 19(4), 1-12. https://www.researchgate.net/profile/Bernatal_Saragih/publication/341000876_ /links/5ea95042a6fdcc7050979106

SatgasCOVID-19. (2021). Data Sebaran Virus COVID-19 Update 28-01-21. Kupang: SATGAS COVID-19.http;//COVID-19.go.id/Satgas COVID -19

World Healt Organization-WHO. (2021). World Health Organization Coronavirus disease 2019 Global situation 2021. Swiss: WHO. https:// www.who.int/emergencies/disease/novelcoronavirus-2019.

WHO. (2021). Global Situation $2021 . \quad$ Swiss: WHO.https://www.who.int/emergencies/disease/novelcoronavirus-2019. [diakses pada tanggal 1 september 2021

WHO. (2021). Global Situation $2021 . \quad$ Swiss: WHO.https://www.who.int/emergencies/disease/novelcoronavirus-2019. [diakses pada tanggal 1 september 2021

Yuniar, R. (2020). Larangan Plastik di Tengah PSBB Jakarta. Jakarta: BBC News $\begin{array}{llll}\text { Indonesia. } & \text { Retrieved } & \text { December } & 2020\end{array}$ https://www.bbc.com/indonesia/majalah-53275980 